Article

\title{
FIX IT BLACK JESUS: The Iconography of Christ in Good Times
}

\author{
Robin R. Means Coleman ${ }^{1}$ and Novotny Lawrence ${ }^{2, *}$ \\ 1 Department of Communication, Texas A\&M University, College Station, TX, 77843, USA \\ 2 Greenlee School of Journalism and Communication/Department of English, Iowa State University, \\ Ames, IA 50014, USA \\ * Correspondence: novotnyl@iastate.edu
}

Received: 21 May 2019; Accepted: 23 June 2019; Published: 28 June 2019

check for updates

\begin{abstract}
Good Times is primarily remembered for the situation comedy that it became, rather than how the series began. As a part of what Means Coleman classifies as "The Lear Era: Social Relevancy and Ridiculed Black Subjectivity," the series was the first sitcom in TV history to feature a loving, working-class, Black nuclear family - the Evanses - with a focus on recounting their racial and socioeconomic challenges and gains. While the representational treatment of the Evanses as a whole and full family by network television (CBS) was groundbreaking, Good Times, perhaps, still reinforced implicit schemas regarding Blackness as the Evanses were poor and lived in Chicago's rough-and-tumble Cabrini Green Housing Projects. Further, as the series progressed, narrative attention focused on the character J.J., a 'Jim Crow' stereotype (i.e., eye-bulging, wide-smiling, hustler) whose emergence as the centerpiece of the series eventually prompted co-star, John Amos, to leave the once stereotype-busting show out of protest. Although Good Times ultimately fell into the stereotype trap, the first two seasons of the series worked effectively in representing Blackness as complex and worthy. This article focuses on "Thank You Black Jesus", a season-one episode that centers on J.J.'s painting of Black Jesus, an artistic interpretation that is in line with the Bible's description of Jesus. "Thank You Black Jesus" begs several important questions surrounding religious and secular symbols, the interpellation and hailing of Blackness, and faith or suspending one's disbelief. In this article, we conduct a critical, cultural analysis to explore the meanings that are associated with symbols, Blackness, and faith. We also consider the staying power of the "Black Jesus" episode in contemporary popular culture, as witnessed in the form of memes, intertextual references to the episode in other media texts, and as elucidated by continued debates surrounding the race of Jesus and the ways to pursue an iconography of inclusiveness.
\end{abstract}

Keywords: African Americans; television; sitcoms; popular culture; Black Jesus

"Just tell me I'm doing the right thing not having the baby." (Maude)

"Nigger, what the hell did you just say!" (The Jeffersons)

"How do we know Jesus wasn't Black?" (Good Times)

There was a risky boldness that came with the CBS network's 1970s situation comedies. Maude's titular star was a middle-aged, White-progressive-feminist on her fourth marriage, who, in the groundbreaking two-part episode called "Maude's Dilemma", resolved to have an abortion after an unexpected pregnancy.

Over the course of the series, The Jeffersons, primarily through its leading character, George, a cantankerous, successful, Black male entrepreneur who lives in a "deluxe apartment in the sky" in Manhattan's trendy Upper East Side, repeatedly tossed around the n-word. He did so with a carefree ease (and absent a censor's beep) among his African American friends, as well as in racially mixed company. 
Good Times is hailed as the first sitcom in network TV history to feature a Black nuclear family. The series focused on the Evanses, a tight-knit, loving, working-class family living in Chicago's Cabrini Green Housing Project. Socio-politically attuned, Good Times, through the Evans family, daringly demanded us to rescript the familiar iconography of a White Jesus with, perhaps more accurately, a Black one.

The aforementioned shows-Maude, The Jeffersons, and Good Times-presented themes that, by today's standards, might seem relatively tame, especially in comparison to those that are examined in sitcoms on post-network television, such as cable TV and through streaming services. However, in the 1970s, these and other programs, which variously worked to attend to Black life and culture (Blackness) in more fully developed ways, were revolutionary, given African Americans' tumultuous beginnings on the burgeoning medium of television in the 1950s. The inaugural TV sitcoms developed around Black characters were firmly rooted in theater's blackface minstrelsy, which featured,

White and, later, Black entertainers corked up, donning absurdly exaggerated, often hideous blackface makeup to create a visual image of the comic Stage Negro; ill-fitting clothing, malaprops, nonsensical chatter, a slavering addiction to watermelon and chicken, a shuffling gait and/or contrasting propensity to break into frenzied dance or flight when in earshot of syncopated music or eyesight of a cemetery, were added to complete the picture. (Taylor and Austen 2012, p. viii).

This racist, popular entertainment form crossed over to the film industry where White performers, such as Walter Long and Shirley Temple, donned blackface in the pro-Ku Klux Klan film, The Birth of a Nation (1915), and the pro-slavery film, The Littlest Rebel (1935), respectively. The problematic tradition also transitioned to radio where the blackface makeup gave way to blackvoice, an aural signifier that White performers used to portray "authentic" Black speech using malapropisms, broken English, and other stereotypes to connote ignorance. Beulah (1950-1953) and Amos ' $n$ ' Andy (1951-1953), which were two early TV shows centering on Black characters, originated as blackvoice radio programs. The Beulah serial featured the eponymously named character, but a White man, Marlin Hurt, voiced her. Amos ' $n$ ' Andy's title characters were conceived and performed by former White vaudevillians, Freeman Gosden and Charles Correll. Beulah was yet another an all-seeing, nurturing mammy, taking care of a white family, and Amos and Andy were dim-witted and conniving and would seemingly do anything to avoid gainful employment.

Though Black actors stepped into all three roles when the programs transitioned to TV, they remained emblematic of the most egregious Black stereotypes. After three seasons, three different actresses in the title role, and a change in production location, Beulah was removed from ABC's broadcast schedule. Amos ' $n$ ' Andy's run was shorter, primarily due to the National Association for the Advancement of Colored People's (NAACP) vehement protests, which ultimately led CBS to remove the series from its broadcast schedule after two seasons. As a result, Black-themed programs disappeared from TV after the cancellations of the shows, thrusting the medium into what Means Coleman designates "The Nonrecognition Era," a 13-year period during which African Americans virtually disappeared from television, particularly starring in situation comedies (Means Coleman 2000, p. 82).

Although Blacks and their shows largely vanished from television in the 1950s and 1960s, Whites, on the other hand, thrived in sitcoms, particularly in what David Marc refers to as "Waspcoms" (Marc 1998, p. 45). These homogeneously White programs, such as Father Knows Best (1954-1960), The Many Loves of Dobie Gillis (1959-1963) and The Andy Griffith Show (1960-1968), depicted sanitized, saccharine White idylls that entertained audiences and reinforced the sanctity and virtue of White family life in the process. This formula of Black erasure and the centering of Whites and Whiteness was so successful that many of the programs enjoyed lengthy runs and spawned spin-off series during a time when African Americans were engaged in the struggle for social, economic, and political equity.

TV networks gradually reentered the Black sitcom business beginning in the late 1960s in response to the Civil Rights Movement and the NAACP's persistent demands for representational equality. This renewed foray began with two programs, Julia (1968-1971) and The Bill Cosby Show (1969-1971), 
which starred actor and Civil Rights activist, Diahann Carrol, and comedian, Bill Cosby, respectively. The former chronicled the eponymous character, a firmly middle-class nurse and widow (her husband died in Vietnam), raising her six-year old son in a predominantly White, lavish apartment building, while the latter focused on high school gym teacher, Chet Kincaid, and his relationships with his students and overbearing principal. Importantly, both Julia and The Bill Cosby Show were significant departures from the buffoonery that circumscribed Beulah and Amos ' $n$ ' Andy, in that they centered on educated, hardworking Black characters who were productive members of society. Hence, the minstrel-inspired caricatures whose antics had once led viewers to laugh at African Americans, gave way to situational humor derived from Julia learning to navigate issues, such as the challenges of single parenthood, and Chet's attempts to motivate his uninspired students.

Importantly, Julia and The Bill Cosby Show's more respectable characterizations came at a significant cost. Both of the series were the epitome of assimilationist discourses, or programs " ... characterized by a rejection of Blackness to the extent that there is no reference to Black culture, there are no sociopolitical conflicts (e.g., racial or economical), and difference yields to mainstream conformity" (Means Coleman 2000, p. 83). Particularly, Julia and Chet resided in integrated worlds, where they were, to a moderate extent, isolated from other African Americans and insulated from the late 1960s socioeconomic and political climate. Consequently, seminal events, such as the assassination of Dr. Martin Luther King, Jr. and the emergence of the Black Power and Black Pride Movements, did not factor into their lives. Further, in typical sitcom fashion, neither character was ever afforded the opportunity to truly challenge casual or systemic racism, because episodes that dared to broach instances of racial discrimination either presented them as simple misunderstandings or as out of the ordinary occurrences rather than as incidents that consistently informed Julia and Chet's everyday existences (Acham 2004, p. 121). As a result, Julia and The Bill Cosby Show seemed to be out of touch with the politics of the day, a point that is evidenced by the consistent criticism that the former endured during its three-year run. Tired of fighting with the show's producer about delving deeper into Black identity and culture, and exhausted from constantly defending Julia's depiction of African American life, Diahann Carol decided against signing on to appear in a fourth season of the series, which effectively ended its broadcast run. The Bill Cosby Show's departure from television was much less dramatic, as audiences simply did not connect with the program. The series garnered mediocre ratings and was subsequently cancelled after two unremarkable seasons.

Fortunately, as TV progressed into the 1970s, the medium tapped into the US's tumultuous political climate in a host of new more radical sitcoms that functioned as social commentaries as they entertained. Significantly, this period also moved away from assimilationist discourses instead featuring Blacks in sitcoms in which they often drove the sociopolitical discourse. Thompson explains that the sitcoms' shift from the saccharine of the 1950s to the edgier fare of the 1970s with their acknowledgment of pressing social, economic, and political concerns can be linked to one series: "'All in the Family' changed that in one fell swoop. Television went from being a medium that virtually ignored what was going on in the real world to one that went in the other direction" (Mitchell 2006).

Indeed, All in the Family's Archie Bunker, a conservative bigot who freely used racial epithets, and opposed school desegregation, ending the Vietnam War, and the Women's Movement, only to end up being proven wrong at each episode's end, was a character unlike any other before him. The series became an instant hit, demonstrating the ratings viability of so-called sit-commentary, and leading to the development of similar shows, including All in the Family spin-off, The Jeffersons (1975-1985), Sanford and Son (1972-1977), Maude (1972-1978), and the primary focus of this article, its spin-off, Good Times (1974-1979).

These radical, innovative narratives have a single tie that binds them - they were all Norman Lear productions. Lear, a progressive himself, is known as much as a television writer and hit-maker as he is for taking up politically astute and often controversial themes in his programs. In a personal interview that was conducted in 2013, the iconic producer explained that everyone working on his shows kept copies of the Los Angeles Times or The New York Times close, and as such they were all especially attuned 
to events that were taking place in the country: "We were scraping the barrel of our own experience and finding our storylines there" (Lear 2013). Lear's comedies advanced verisimilitude-infused humor rather than offering viewers sappy, moral reprieve by directly addressing the tumultuousness of the times-antiwar protests, the Civil Rights Movement, the Women's Movement, police brutality, poverty, as well as sexual assault, child abuse, breast cancer, gay rights, and interracial relationships.

Family and Maude illustrated that Lear's socially conscious approach to sitcoms was viable; yet, those series both focused on White families. When Lear pitched a new series, Good Times, network executives, with their constant focus on the economic bottom line, expressed initial concern that a show about an African American family would only appeal to a small segment of the Black audience. Lear disagreed, firmly believing that, as long as the show was funny, it would connect with all audiences (Lear 2013). He pressed forward, developing the series with Black upstart writer and producer, Eric Monte, and actor, Mick Evans who had achieved success in his recurring role as the wise and level-headed Lionel Jefferson on All in the Family.

Good Times focuses on the Evanses-parents, Florida (Esther Rolle) and James (John Amos), and their children, J.J. (Jimmy Walker), Thelma (Bern Nadette Stanis), and Michael (Ralph Carter)—who share a loving, joyful, familial bond, despite structural economic, political, and racist hurdles that impeded their upward mobility. The program's effective blend of comedy and systemic critique was well received when Good Times debuted:

The actors all scored in their roles, and when the show aired it was an immediate hit. And not with Blacks only, as some predicted would be the case. The viewership was 60 percent White. It was heralded as a breakthrough by the press generally and the Black press especially, the actors were proud and excited, and it was a kick sitting down each week to a reading of the new script. (Lear 2014, p. 270)

Indeed, Good Times was initially a politically perceptive program that addressed a range of socially relevant topics. Specifically, season one episodes, such as "Too Old Blues," "Michael Gets Suspended," and "Sex and the Evans Family," examined age discrimination in employment, the educational system's exclusion of slavery to promote favorable legacies of prominent White historical figures, and teenage sexuality, respectively. Good Times continued exploring socially relevant topics in season two, during which school bussing, racial profiling/police harassment, and gang violence are the subject of "Crosstown Buses Run All Day, Doodah, Doodah," "J.J. Becomes a Man," and "The Gang." Yet, the series was not without its flaws. Means Coleman classifies it as part of "The Lear Era: Ridiculed Black Subjectivity and Social Relevancy," in part because the show featured the Evans family in a separate, unequal world, communicating "that Whites and Blacks cannot, should not, and will not, coexist without deleterious results that are based on one group's (African Americans) difference, if not deficiency" (Means Coleman 2000, p. 89).

Regrettably, as the series progressed, narrative attention shifted from the family "scratchin' and survivin'", as the opening theme portends, to the J.J. character, a Jim Crow stereotype that was marked by clownish behaviors, physical humor, outrageous dress, and malapropisms. J.J.'s emergence as the centerpiece of the series sowed discord among the cast and writers. John Amos and the late Esther Rolle fought with producers over the show's emphasis on their TV son J.J, with his toothy grin, bug-eyed antics, and trademark catchphrase, "DY-NO-MITE" (Mitchell). Yet, their concerns went largely ignored due to Good Times' strong ratings, and because J.J. became exemplary of the far-reaching economic gains of a popular TV character. He developed a following among kids who purchased J.J. merchandise, including t-shirts, pajamas, and belt buckles (Bogle 2001, p. 202). Thus, Good Times is largely remembered for the troubled situation comedy that it became as a result of its shift from a series exploring Black family life to contemporized minstrel show complete with memorabilia, rather than the groundbreaking, thoughtful sitcom that it had once set out to be. 


\section{1. "Thank You Black Jesus"}

Although Good Times failed to fully live up to the lofty expectations that are associated with being the first series to present a socially relevant Black nuclear family, as previously noted, early episodes did include significant critiques that continue to resonate in contemporary popular culture. "Rich and Lahendro (2003)" (1974, Season 1, Episode 2), is among the most notable, as it tapped into the 1970s zeitgeist, a time that was defined by hard-hitting issues, such as the Vietnam War, alongside ongoing struggles for racial and gender equity, and gay rights. This was also a time of experimentation with illicit drugs, fad diets, and religious exploration that had begun in the 1960s. For instance, in the 1970s, Hinduism gained more attention as a result of Maharaj-ji's Divine Light Mission and Swami Muktananda's Siddha Yoga Dham Movement. Further, cults such as Heaven's Gate, which "was based on the premise that aliens would escort people to the Kingdom of Heaven via extraterrestrial spacecraft," as well as Jim Jones' Peoples Temple serve as other prominent examples of the religious groups that thrived as a result of people's spiritual quests (Yuko 2017).

It is only logical that Good Times injected serious religious critique into an episode, given Lear's penchant for keeping his finger on the national pulse. In doing so, "Thank You Black Jesus" also forcefully challenged the representational status quo by: (1) depicting the Evans family engaging with art; (2) reforming the image of Jesus as fixed to a fluid symbol inviting new constructions; (3) inviting viewers to consider the impact and power of representation, cultural history, and religion upon their understanding; and, (4) introducing the notion of faith (versus luck).

"Thank You Black Jesus" opens with J.J. completing a portrait of neighborhood hustler and criminal, Sweet Daddy Williams, whose greatest feat is having been shot five times and living to tell the tale. Given Williams' nefarious background, J.J.'s younger brother Michael does not view him as worthy of the portrait and Michael's disdain for the painting is compounded by the fact that it is also the beginning of Black History week. This celebratory week is a time for reflection and honoring those who put their lives on the line in the battle for racial equality in Michael's eyes. He explains to J.J. that, in celebration of Black History week, the Pan African Council is sponsoring an art show and encourages him to enter "a better painting" in an attempt to win a cash prize. In rooting through a closet, Michael discovers what he believes to be the ideal painting, one that was previously created by J.J.-a Black Jesus. In true sitcom fashion, hijinks ensue when Michael replaces the picture of the White Jesus that adorns the wall in their apartment with J.J.'s painting of Black Jesus, which causes the family to consider representations of Jesus and the tenets of Christianity, more broadly.

"Thank You Black Jesus" is a standout Good Times episode, (and the series more broadly), as a result of its portrayal of a Black Arts tradition and the Evanses engagement with it. The series foregrounds the work of former football player-turned-painter, Ernie Barnes, who painted in a style of art composition that is known as the Black Romantic. Barnes' painting, "The Sugar Shack", is the most recognizable from the series as it served as the backdrop for Good Times' closing credits during its entire run (Figure 1). Depicting a group of Blacks with slightly elongated limbs, deeply and freely dancing to the rhythms of a band in what can be described as a "juke joint," the painting provides a glimpse into a form of African American celebratory culture. Barnes provided insight regarding the painting's conception and meaning in a 2008 interview: "The Sugar Shack' is a recall of a childhood experience. It was the first time that my innocence met with the sins of dance. The painting transmits rhythm, so the experience is re-created in the person viewing it. To show that African-Americans utilize rhythm as a way of resolving physical tension" (Qtd. in Ayubu 2011). Given that the Evans family consistently deals with the emotional and physical tensions that are associated with being Black and poor, "The Sugar Shack" functions as a continuance of each show's narrative. Moreover, in addition to using Barnes' paintings to highlight the Black Arts tradition, Good Times borrowed heavily from the artist's style in the course of presenting J.J.'s paintings and akin aesthetic. 


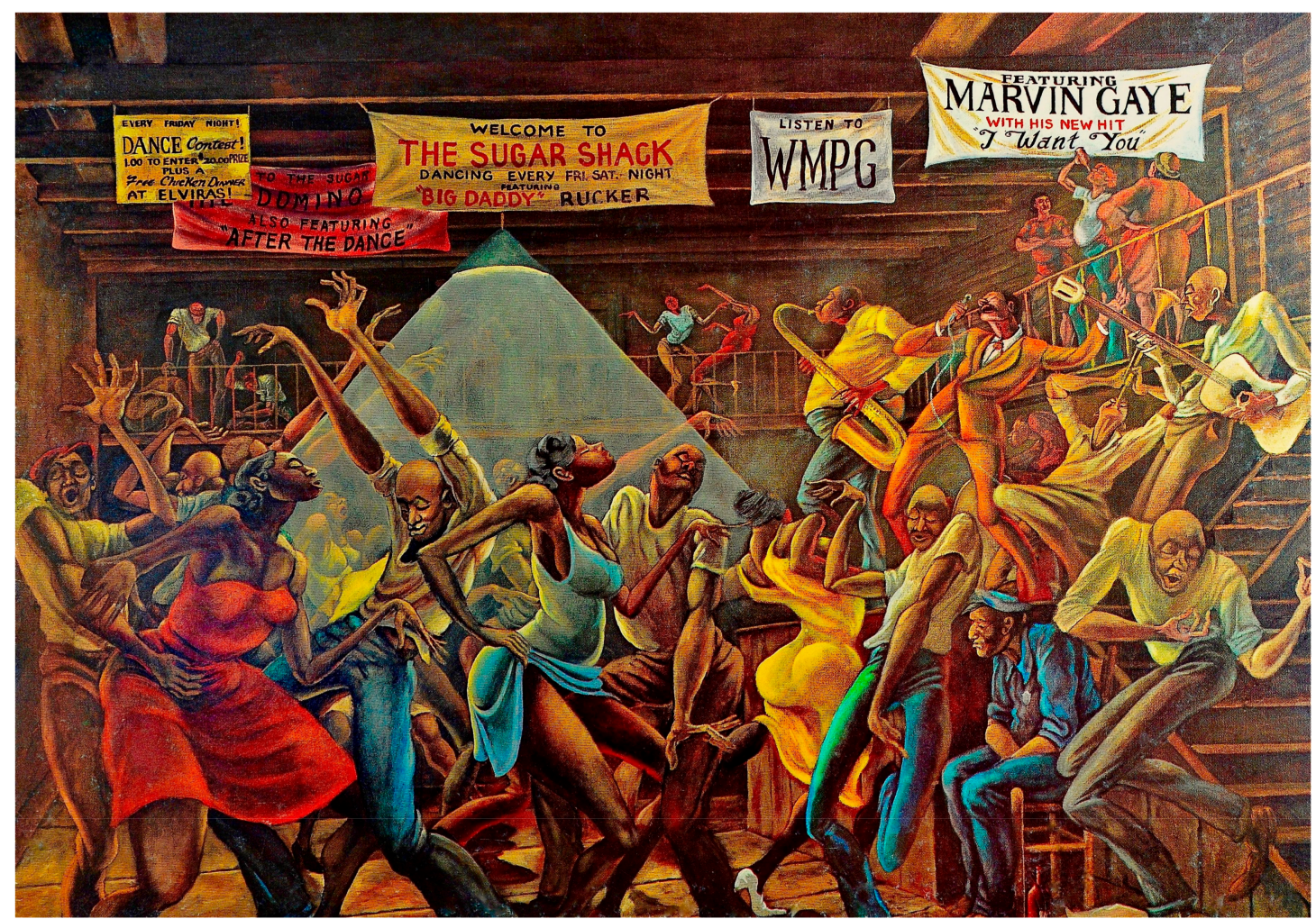

Figure 1. "The Sugar Shack" by Ernie Barnes.

With Good Times' portrayal of a Black Christ figure in a color palette that was similar to that used by Barnes, the painting of Black Jesus featured in the episode is reminiscent of works created in the Black Romantic style. Accordingly, the painting is significant in that it functions as a powerful narrative device that allows for the series to address Whiteness, religious symbols, and faith. The emphasis on situating the rendering of White Jesus as a religious "symbol" rather than an artifact that has the power to contribute to notions of White supremacy or as a close approximation of historical fact is worth noting.

The painting of White Jesus used in the episode closely resembles painter Warner Sallman's now iconic painting of what he imagined Christ's profile to be (Figure 2). A Chicagoan and Christian born in 1892, Sallman was a commercial illustrator and evangelist who spent much of his career spreading the Gospel through his art. Tasked with creating cover art for a 1924 issue of a religious magazine, Sallman settled on rendering an image of Christ, but struggled with the representation. He is said to have been advised by an administrator at the Moody Bible Institute to "make Him a real man! Make Him rugged, not effeminate. Make Him strong and masculine, not weak, so people will see in His face that He slept under the stars, drove the money changers out of the temple, and faced Calvary in triumph" (Spear 1997, 205). The result was his "Head of Christ," which has become one of the most reproduced images-over 500 million times by the end of the 20th century-in United States (U.S.) mass culture history (Morgan 1996, 26). Hence, it was this image that became mass (re)produced for religious devotion, appearing on prayer cards, candles, tapestries, lithographs, jigsaw puzzles, hand-held fans, mugs, and knickknackery. 


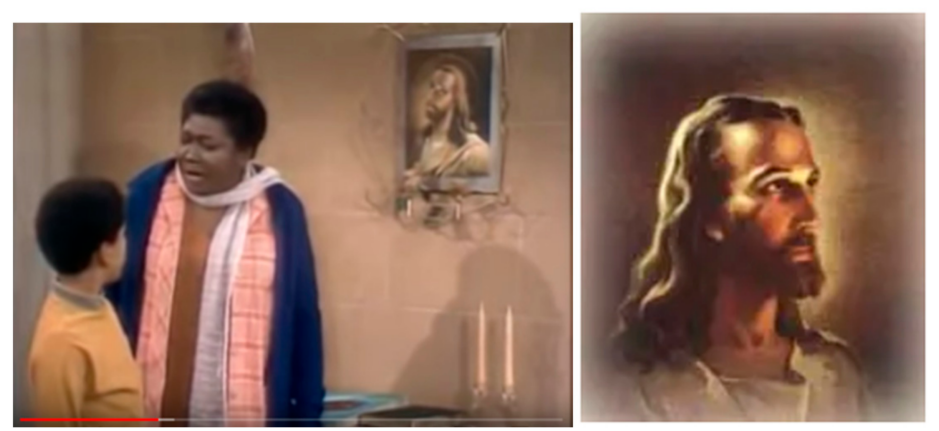

Figure 2. The painting of White Jesus displayed in the Evans home (left), and Warner Sallman's mass-produced painting of White Jesus (right). Screenshot captured from "Thank You Black Jesus." Good Times: The Complete First Season, Columbia Tristar Home Entertainment, 2003.

Here, it helps our understanding to consider Richard Dyer's White, in which he examines Whites' cultural production of images of themselves to call attention to both the ubiquity and the invisibility of Whiteness (1). Dyer explains that Whiteness exists as nothing at all, while people of color are distinctly marked as visibly and excessively raced.

The sense of Whites as non-raced is most evident in the absence of reference to Whiteness in the habitual speech and writing of White people in the West. We (Whites) will speak of, say, the Blackness or Chineseness of friends, neighbors, colleagues, customers or clients, and it may be in the most genuinely friendly and accepting manner, but we don't mention the Whiteness of White people we know. (Dyer 1997, p. 2)

This use of seemingly innocuous language upholds White supremacy by continually affirming Whiteness as the norm to which all other racial groups are compared. Hence, Dyer works to make "Whiteness strange,", in the attempt to illustrate its functioning and ubiquity, and to upset the balance of the racial status quo that favors Whites over minoritized people of color.

Dyer's work is particularly useful in examining "Thank You Black Jesus,", which, in a similar vein, challenges White ubiquity and its existence as if nothing at all. In particular, the mass-produced versions of Jesus are the commonly accepted norm, so much so, that re-imaginings that are more in line with His description in the Bible often generate controversy. To illustrate, in 1989, singer Madonna's "Like a Prayer" music video turned into a representational minefield due to its portrayal of a Black Jesus, who the singer affectionately kisses. More recently, Boondocks creator, Aaron McGruder stirred controversy with his Adult Swim TV series, Black Jesus (2014-2016), which presents an African American version of the deity that is working to spread love in a rough neighborhood in Compton, CA. The content of the trailer for the series was deemed to be offensive and blasphemous by organizations, such as Chicago's House of Prayer for All Nations, and conservative Christian activist group, One Million Moms (Kuruvilla 2014).

"Thank You Black Jesus" interrogates the White-Jesus-normal/Black-Jesus-as-Other binary using an all-Black space; specifically, the Evanses' home. When Michael finds J.J.'s painting of Black Jesus and holds it up next to the image of the White Jesus figure, he calls attention to its Whiteness, illustrating that, even in a Black space, it had existed as nothing at all until placed next to a historically racialized Other (Figure 3). Further, the image of Christ as accurate and normalized is made strange when Michael encourages his mother, Florida, to rethink her assumptions by asking, "How do we know that Jesus wasn't Black? He could have been from the lost tribe of Israel. They were supposed to be Black." When she rejects the notion, commenting that if Jesus was Black the Bible would say so, Michael counters that it does by reading from Revelations, chapter 1, verse 14 which states: "His hair is like wool and His eyes are like a flame of fire." Florida is taken aback by the verse, which is a reaction that deepens when Michael points out that Black Jesus' appearance in the painting is emblematic of the description laid out in the Bible. As a result of her conversation with Michael, Florida's longstanding belief about Jesus' 
appearance are made strange and, as such, she allows for him to hang the more representationally accurate Black Jesus (just) for Black History week in place of the image of the White Jesus.

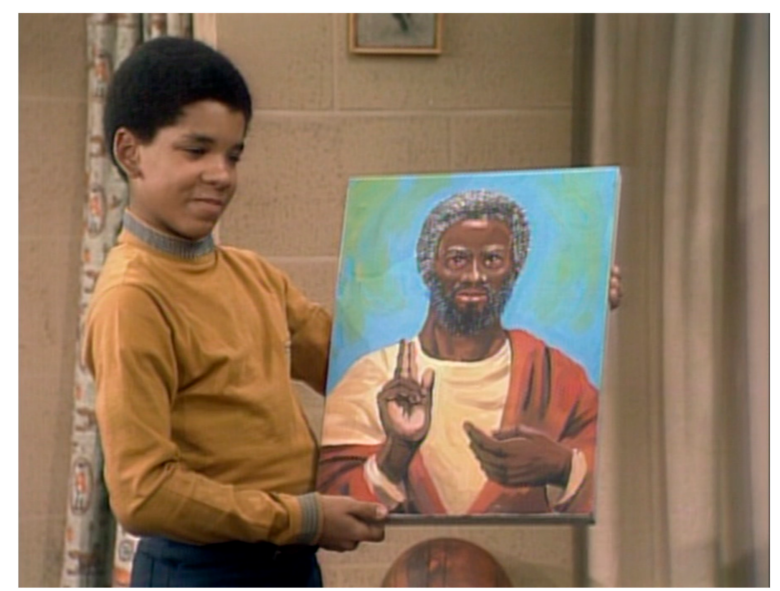

Figure 3. Michael Evans holds J.J.'s painting of Black Jesus. Screenshot captured from "Thank You Black Jesus." Good Times: The Complete First Season, Columbia Tristar Home Entertainment, 2003.

The family patriarch, James, and the rest of the family quickly develop great affection for Black Jesus, as it hangs in their home. Their embrace of the painting is opportunistically motivated by the sudden good fortune that the family begins to experience immediately after taking White Jesus down, replacing Him with Black Jesus. An IRS audit results in James gaining an unexpected windfall. Michael comes home with his own windfall-a $\$ 5$ bribe-after two drivers in a car accident ask him to keep things secret from traffic police. Family friend, Willona, lands a date with the owner of a filling station, who, presumably, will have lots of free gas to give her. Thelma is invited to an Isaac Hayes concert by a boy she has been pining over, "THE Larry Williams." Significantly, James, Michael, Thelma, and Willona's affinity for Black Jesus stems from the tangible "blessings" that they receive as a result of their fealty to their image, which recuperates Blackness as valued, if not sacred.

The luck that the Evanses experience also calls attention to the irony of their faith in White Jesus as it relates to the family's meager circumstance. The argument can be made that the image is endemic of the system that has historically served to socially, economically, and politically marginalize Blacks. Whether through the Federal Housing Administration's (FHA) discriminatory lending practices, the government's defunding of public assistance programs, or in the form of voter suppression, the U.S. has consistently privileged Whites over Black people. Accordingly, the White Jesus painting and its akin iconography of ubiquity-turned-superiority can be read metaphorically as part of a system that devalues (poor, working class) Blacks.

Given their turn of good luck, the family is not only willing to set aside Florida's stalwart attachment to White Jesus and ignore the potentially vexing issue of a non-White Jesus, but they also opt to disregard a still more controversial fact-the model for J.J.'s (sacred) Black Jesus is a neighborhood vagrant, (the profane) Ned the Wino. Ned is described as a "ghetto prophet" who walks the streets proselytizing and predicting Armageddon. He is also a drunkard and a beggar, panhandling for dimes to purchase wine so that he can "die happy."

Ned the Wino as the source image of Black Jesus is an interesting choice, which brings to mind a number of sympathetic associations between Ned's lifestyle and the life of Jesus. Jesus is said to have performed the miracle of turning water into wine, and in Proverbs 31:6-7 the following counsel is provided: "Give strong drink to him who is perishing, and wine to those who are bitter of heart; let him drink and forget his poverty and remember his misery no more." More, on the point of homelessness and being destitute, Jesus, in referring to himself sympathetically offers, "Foxes have holes and birds of the air have nests, but the Son of Man has nowhere to lay His head" (New King James Version, The New Open Bible 1990, Matthew 8:20; Luke 9:58). That quote is followed by Matthew 25:40, in which 
Jesus promises eternal life to those righteous individuals who feed and clothe strangers in need: "Assuredly I say to you, inasmuch as you did it to one of the least of these My brethren, you did it to Me."

The episode "Thank You Black Jesus" concludes with the Evans family's good fortune running out. Still, Black Jesus finds a place in their hearts and in their home as at the episode's end, the painting keeps its place of honor, hanging on their wall. Unfortunately, the ensuing episodes would see Black Jesus, without explanation, disappear from the Evans' home and the White Jesus portrait return.

\section{The "Fix it Black Jesus" Meme}

Though Black Jesus disappeared from Good Times, the painting continues to resonate in contemporary popular culture. In somewhat Biblical fashion, J.J.'s Black Jesus was resurrected in the 2000s as a digital meme. The meme, which is a screen grab from the "Thank You Black Jesus" episode, shows Florida gazing at the Black Jesus painting as it hangs on the wall. In white, bold capital letters at the bottom of the image "FIX IT BLACK JESUS" appears (Figure 4).

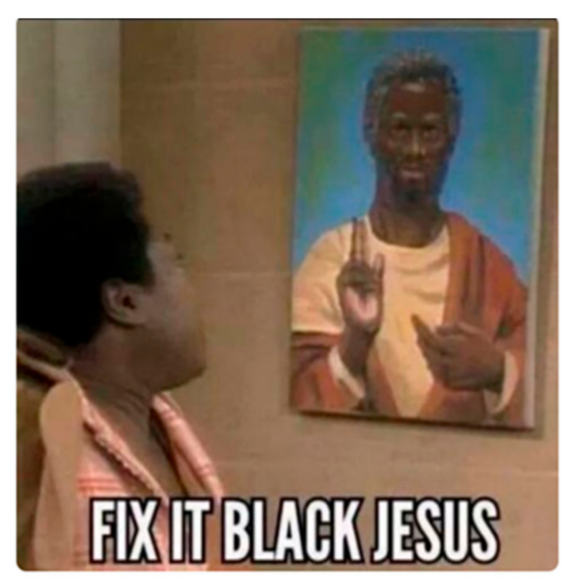

Figure 4. "Fix it Black Jesus" meme.

Given its intertextual nature, the meme invites humor by drawing on its wellspring, Good Times. However, it is what Black Twitter users (here "Black Twitter" is broadly termed, no matter the digital platform used) have done with the meme that has elevated its humor and, perhaps, allowed the Good Times' version of Black Jesus to thrive. It has become a sardonic, clap back at social shenanigans (often, but not always, played out by Whites). Brock, in his article, "From the Blackhand Side: Twitter as a Cultural Conversation," defines and describes Black Twitter's cultural significance and discursive power:

Black Twitter is Twitter's mediation of Black cultural discourse, or "signifyin"' (Gates, 1983). In particular, Black hashtag signifying revealed alternate Twitter discourses to the mainstream and encourages a formulation of Black Twitter as a "social public" [ ... ] Thus, signifyin' becomes a practice where the interlocutor inventively redefines an object using Black cultural commonplaces and philosophy. (Brock 2012, pp. 530, 533)

To illustrate, Black Twitter weighed in on a number of instances in 2017 and 2018 of Whites calling the police on Blacks for going about their daily lives. For example, when a White woman, Jennifer Schulte, confronted, harassed, and then called police on a Black family barbequing in an Oakland City, CA park, Black Twitter dubbed her "BBQ Becky" and circulated video of the event on social media. Commenters added the hashtag, \#Fix it Black Jesus, and posted to social media the Good Times-inspired Fix It Black Jesus meme. Further, that meme galvanized people to create another iteration featuring Evans family patriarch, James, subtly encouraging people to consider the ethnicity of the deity to whom they pray (Figure 5). 


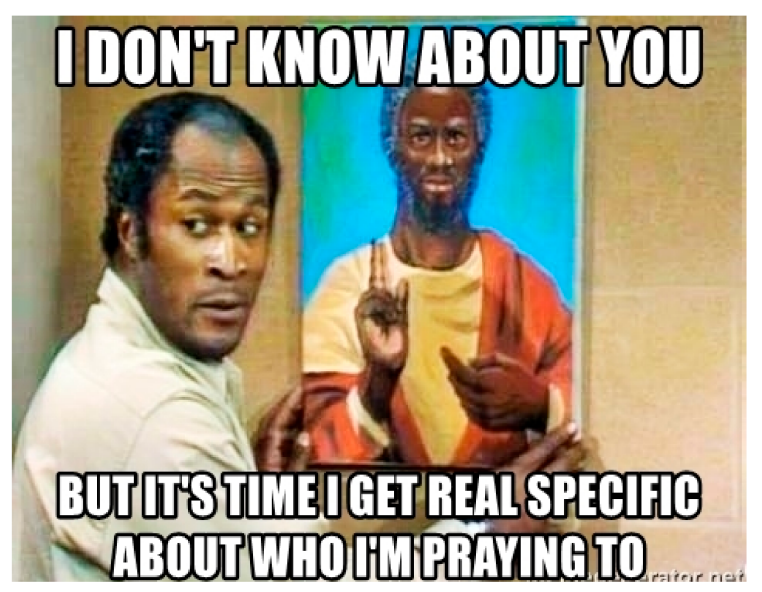

Figure 5. “I Don't know about You, but it's Time I Get Real Specific about Who I'm Praying to"meme.

However, references to Black Jesus do not always carry the Good Times image and they need not be in response to head-scratching moments of bigotry. For example, when Texas A\&M University's first Black head football coach, Kevin Sumlin, took the team to a 10-2 regular season, he was humorously cast as the Black messiah. On 26 November 2012, Sumlin's Wikipedia page was modified to seemingly celebrate his success by calling him "Black Jesus" and changing his title from "head coach" to "boss" (Figure 6). Though none, deity or otherwise, could protect Sumlin from Texas A\&M fans who turned on him in 2017 by sending him racist death threats, including an image of a letter that was shared by the Sumlins on Twitter: "You suck as a coach! You're a nigger and can't win! Please get lost! or else."

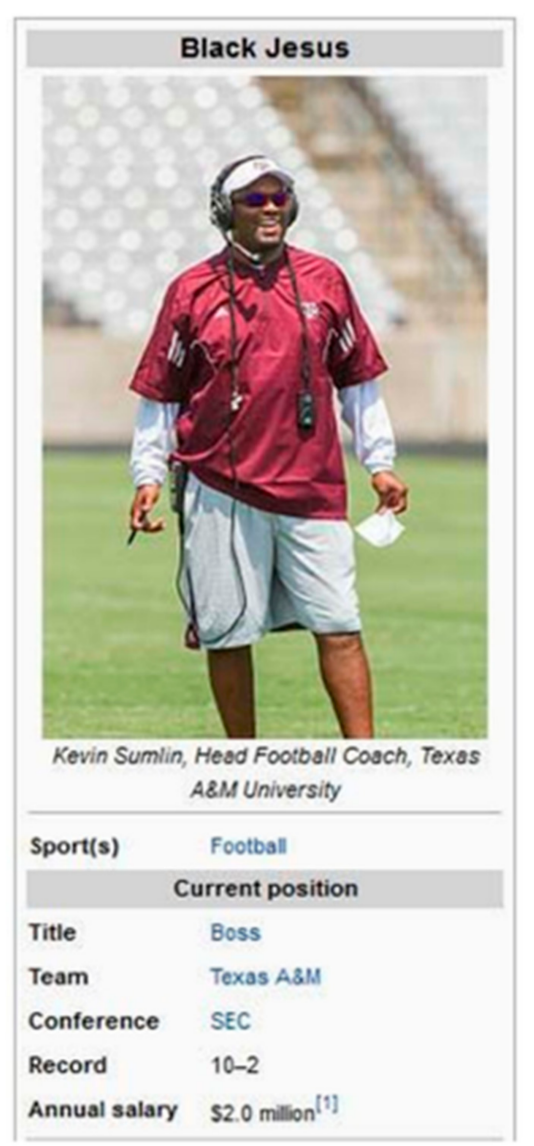

Figure 6. Texas A\&M Head Football Coach, Kevin Sumlin. Screenshot taken from Sumlin's Wikipedia page. 


\section{Black Jesus Lives on: TV, Film, and Art}

In August 2014, Aaron McGruder of Boondocks fame (comic strip and Cartoon Network series) premiered his situation comedy, Black Jesus (2014-present), on the Cartoon Network. Starring Gerald Johnson as Jesus Christ, the series is set in contemporary Compton, CA and it features Jesus and his less-than-perfect-stoner buddies hanging out and getting into farcical scrapes-most of which have something to do with securing weed or freeing themselves from various hustles. Jesus' friends understand that he is God's son, but also recognize that he is fallible and accessible. He is a cool, hip, and often foul-mouthed friend who cares deeply and works hard to be on the right side of things, which is, presumably, the life lesson for us all. Consequently then, the program also challenges White ubiquity by making viewers of the series ask when confronted with challenging situations in their everyday lives, "What Would Black Jesus Do?"

The premiere of Black Jesus served as a reminder that there were also earlier media references on the subject. For example, Valerio Zurlini's 1968 film, Black Jesus (1968), starring Woody Strode was no laughing matter. An Italian drama, Black Jesus is inspired by the life of Congolese politician and anti-colonialist/independence leader Patrice Lumumba. It tells the story of Maurice Lalubi, a Congo rebel leader, who is imprisoned by the military. Jailed on trumped up charges, the freedom fighter is tortured, thereby making room for some key religious iconography, before being martyred. Lalubi's death further radicalizes the citizenry.

A 2001 BBC documentary entitled, Son of God, used forensic anthropology to construct an image of what Jesus might have looked like. Countering the "Head of Christ" constructions, the BBC documentary presented a computer-animated presentation of Jesus with a broad nose, dark olive skin, and short hair (Figure 7).

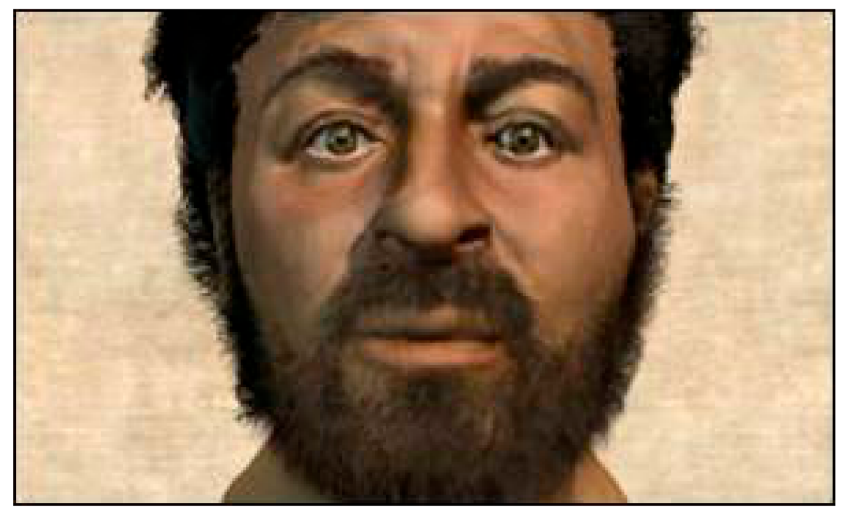

Figure 7. Image of Jesus constructed in BBC documentary, Son of God.

The 2006 film, Color of the Cross (2006), by and starring Jean-Claude La Marre, similarly works to reform the popular "Head of Christ" construction. The film not only depicts a Black Jesus-a dark-skinned Black man-but it also rescripts his persecution to be rooted in racial animus. The Romans not only target Jews for execution, but also have a particular hatred for Black Jews, which leads to Jesus' death and crucifixion.

Though not an exhaustive accounting of the representations of Black Jesus in media (for example, Family Guy's stereotypical Black Jesus is as uninspired as it is forgettable), there is one final image that continues to reign as an innovative celebration of symbolic inclusion. A pointed counter to "Head of Christ," Janet McKenzie's (1999) portrait, "Jesus of the People," features a dark-skinned Jesus modeled by a woman (Figure 8). McKenzie's art is a purposeful, radical act of diversity. She explains, "'Jesus of the People,' however, was not created to be sensational or to create controversy-I simply hoped my then-15-year-old nephew, a young man of color, might find renewed joy seeing a version of his beautiful, dark face reflected back in an icon of Jesus" (McKenzie). 


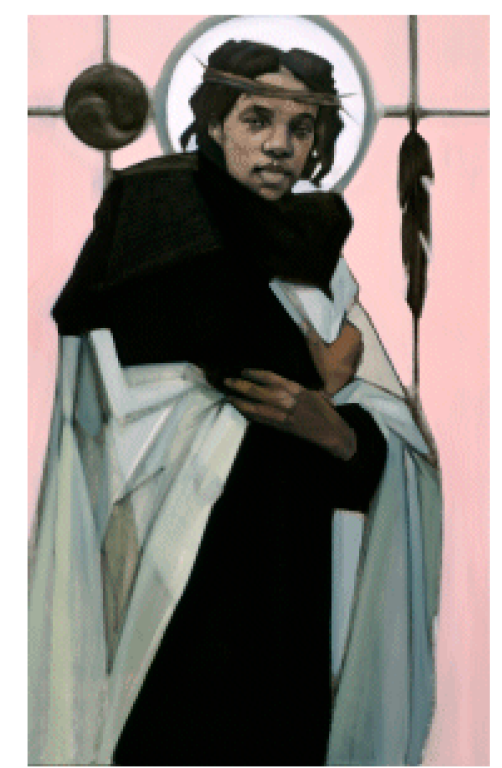

Figure 8. "Jesus of the People" by Janet McKenzie.

For McKenzie's efforts, her painting was selected First Place Winner of the National Catholic Reporter's global competition by juror, Sister Wendy Beckett, of the BBC. The award generated a swell of media interest, which, in turn, prompted hate mail and death threats. She recalls, "I received death threats, my mail was separated for fear of letter bombs, and I was told if I painted Mohammed the same thing that happened to Salman Rushdie would happen to me" (McKenzie). Still, the interest in and love for her painting endures. In 2013, as part of an invited Lectureship at Harvard University, "Jesus of the People" was exhibited on the altar of Harvard's Memorial Church. Her reaction to the exhibition is perhaps, the best reminder of the importance of studying Black Jesus iconography. McKenzie shares, "while waiting to speak I looked at the painting displayed on the altar and it was emotional. I was reminded not only of the very hard and challenging, and at times joyful, journey I have experienced in response to the painting but more importantly, the long road we still have ahead of us to eradicate racial and gender prejudice and violence" (McKenzie).

\section{Conclusions}

In the end, the Good Times episode, "Thank You Black Jesus," should be hailed for taking up important questions regarding the ubiquity of Whiteness, symbolism, the blurring of the sacred and the profane, the interpellation and hailing of Blackness, faith and luck, and political humor. In this article, we have conducted a critical, cultural analysis to explore the meanings that are associated with Black Jesus to reveal not only the social relevancy of the Good Times episode in ongoing discussions about Christ's appearance, but also to lay bare the staying power of the "Black Jesus" episode in today's popular culture. Good Times' Black Jesus has survived for over four decades and crossed media platforms in the form of intertextual references to the episode to reveal that debates regarding the race of Jesus, ways to pursue an iconography of inclusiveness, and Blackness as strange continue.

Author Contributions: This article was an equal co-authorship. Drs. Means Coleman and Lawrence both screened the episode, "Thank You Black Jesus," researched the topic, and wrote the article, which is a critical cultural analysis examining "Thank You Black Jesus," its enduring transmedia presence, and Black religious iconography, more broadly.

Funding: This research received no external funding.

Conflicts of Interest: The authors declare no conflict of interest. 


\section{References}

Acham, Christine. 2004. Revolution Televised: Prime Time and the Struggle for Black Power. Minneapolis: University of Minnesota Press.

Ayubu, Kani Saburi. 2011. The History of Sugar Shack. Black Art Depot Today. February 7. Available online: https://blackartblog.blackartdepot.com/ethnic-artists/ernie-barnes/sugar-shack-history.html (accessed on 20 May 2019).

Black Jesus. 1968. Valerio Zurlini, . Performances by Woody Strode, Franco Citti, Jean Servais and Salvo Basile. Italnoleggio Cinematografico.

Black Jesus. 2014-2016. Written by Aaron McGruder et al. Mike Clattenburg, and et al., s. Cartoon Network.

Bogle, Donald. 2001. Primetime Blues: African Americans on Network Television. New York: Farrar, Straus, and Giroux.

Brock, André. 2012. From the Blackhand Side: Twitter as a Cultural Conversation. Journal of Broadcasting $\mathcal{E}$ Electronic Media 56: 529-49. [CrossRef]

Color of the Cross. 2006. Jean-Claude La Marre, . Performances by Jean-Claude La Marre, Johann John Jean, Adam Green and Jesse Holland. Nu-Lite Entertainment.

Dyer, Richard. 1997. White. London: Routledge.

Kuruvilla, Carol. 2014. Christian Groups 'Violently Offended' about Adult Swim's 'Black Jesus' TV Series. Daily News, June 24. Available online: https://www.nydailynews.com/entertainment/tv/christian-groupsviolently-offended-black-jesus-series-article-1.1879233 (accessed on 20 May 2019).

Lear, Norman. 2013. Personal interview, September 16.

Lear, Norman. 2014. Even This I Get to Experience. New York: Penguin Press.

Marc, David. 1998. Comic Visions: Television Comedy and American Culture, 2nd ed. New York: Blackwell.

McKenzie, Janet. 1999. My Story. In National Endowment for the Arts: 50th Anniversary Archive. Available online: https://www.arts.gov/50th/stories/janet-mckenzie (accessed on 20 May 2019).

Means Coleman, Robin R. 2000. African American Viewers and the Black Situation Comedy: Situating Racial Humor. New York: Garland/Routledge.

Mitchell, John L. 2006. Plotting His Next Break. Los Angeles Times. April 14. Available online: https: //www.latimes.com/archives/la-xpm-2006-apr-14-me-monte14-story.html (accessed on 20 May 2019).

Morgan, David, ed. 1996. Icons of American Protestantism: The Art of Warner Sallman. New Haven: Yale University Press.

Spear, Richard E. 1997. The "Divine" Guido: Religion, Sex, Money and Art in the World of Guido Reni. New Haven and London: Yale University Press.

Taylor, Yuval, and Jake Austen. 2012. Darkest America: Black Minstrelsy from Slavery to Hip-Hop. New York: W.W. Norton \& Company.

“Thank You Black Jesus.”. 2003, Good Times: The Complete First Season, Written by John Donley and Kurt Taylor. John Rich, and Bob Lahendro, s. Columbia Tristar Home Entertainment.

The New Open Bible. 1990. New King James Version. Nashville: Thomas Nelson Publishers.

Yuko, Elizabeth. 2017. American Cult: 5 Spiritual Groups that Went too Far. Rolling Stone. September 12. Available online: https://www.rollingstone.com/culture/culture-lists/american-cult-5-spiritual-groups-thatwent-too-far-202224/heavens-gate-1972--1997-202348/ (accessed on 20 May 2019).

(C) 2019 by the authors. Licensee MDPI, Basel, Switzerland. This article is an open access article distributed under the terms and conditions of the Creative Commons Attribution (CC BY) license (http://creativecommons.org/licenses/by/4.0/). 